\title{
$\mathrm{IU} \in \mathrm{LTAL}$
}

\section{The Interferences of Indonesian Grammatical Aspects into English: An Evaluation on Preservice English Teachers' EFL Learning}

\author{
Andini Linarsih \\ Tanjungpura University \\ andinilinarsih@untan.ac.id \\ Dedi Irwan* \\ IKIP PGRI Pontianak \\ Correspondence email: dediirwanphd@gmail.com \\ Muhammad lqbal Ripo Putra \\ IKIP PGRI Pontianak \\ ripoputra87@gmail.com
}

\begin{abstract}
:
Decades-long researches in a language in contact field have proved that when a learner learns a new language, his/her knowledge regarding their first language might interfere with their learning. If it occurs, the learning process will be more challenging. The data in this research was collected by using document study technique on twenty-five research outlines written by preservice English teachers in order to investigate the potential of interferences of Indonesian subject - verb agreement pattern into English. To do so, a descriptive study was adopted. The data was analysed by incorporating error and contrastive analyses. The finding of this research confirmed that four types of subject - verb agreements pattern of English had been interfered by that of Indonesian. The grammatically incorrect sentences, which were caused by such interferences, occurred very individually. It means that the interference varies from one preservice English teacher to another.
\end{abstract}

Keywords: language interference, preservice teachers, subject-verb agreement 


\section{Introduction}

Interlanguage contact in linguistics field has been a hot discussion for decades. The topic has undergone a number of ups and downs and developments. A number of researchers such as Weinreich (1953), Fishman (1971), Poplack, (1983) and Odlin (1989) have conducted pivotal studies which have underpinned the basic concept of this field until recent days. In its early era, researchers tend to apply the term of interference to describe the contact of languages. Weinreich (1953), who is the first one to propose the terms 'interference' in learning language contact, defined language interference as a negative effect of source language ( $\left.L_{1}\right)$ to the process of learning a target language ( $\left.L 2\right)$ by a learner. As implied in the given definition, in its early development, language interference tended to drive researchers to only focus on investigating the negative effect of L1 when it comes to get contact with L 2 in the second language learning process. In 1971, Fishman (1971) proposed a wider definition for the term of interference by involving any number of bilingual phenomena as part of language interference, not only limited to its negative transfer (see also: Poplack, 1983).

The more neutralized concept of inter-language contact was proposed by Odlin (1989), by proposing the term of 'language transfer'. In contrast with the definition of language interference discussed above, language transfer is taking a stance of assuming that language contact is not only giving negative effect, but, in fact, also positive ones. Positive transfer refers to the Second Language Acquisition (SLA) process in which the L1 concept is closely aligned with that of $L 2$, so that $L 2$ learners could get benefit from their prior knowledge with regard to their $L 1$, when they are trying to learn $L 2$. On the other hand, a negative transfer occurs when the $L 1$ concept is not well-aligned with the concept of $L 2$, so that the concept of $L 1$, which they already have in their mind, could potentially drive the learner to misunderstand the $L 2$.

In this research we adopted the term of interference in order to investigate the potential of negative transfer of Indonesian subject - verb agreement pattern into English by preservice English teachers. A number of pre-research investigations conducted likely to show a number of ungrammatical English sentences written by such preservice teachers. The ungrammatical sentences were mostly about the disagreement between subject and verb. We put such problem in serious concern, since the mastery of subject-verb agreement pattern becomes one of compulsory knowledge to master in order to construct correct English sentences. Without having knowledge in such regard, learners will not be able to do so. Our initial assumption was that there had been a decent chance that such ungrammatical sentences were caused by the interference of Indonesian into English (see: Galkina and Radyuk, 2019; Erdocia and Laka, 2018; Dweik \& Othman, 2017; Amin, 2017; Thyab, 2016; SattiHamad and Yassin, 2015; Sabbah, 2015; Wang 2015; Forsyth, 2014; Erarslan and Hol, 2014; Guo, Liu, \& Chen, 2014; Gao, 2013). The preservice teachers could have found the difficulties in second language learning which were caused by the first language or previous language interference. The research which we are reporting now was conducted in order to develop empirical evidences to support such assumption. Therefore, this research had been designed to find out whether the participants of this research had transferred the grammatical aspects of Indonesian into English. 


\section{Literature Review}

To developed empirical basis in designing this research, a number of literatures have been reviewed. The insight drawn from the review processes has shaped the overall processes undertaken in this research. In the following subsections, we present discussion regarding such reviews.

\subsection{Language Transfer}

Language transfer has been a field of research for decades. The notion of language transfer, which was first introduced to linguistic field by Sajavaara (1989), is defined as the influence which occurs between the native language $\left(L_{1}\right)$ and the second language $\left(L_{2}\right)$ because of the similarities and differences between them (Brown, 2007). At first, the notion of "language transfer" was closely in relation to the behaviourist theories, then, Fries (1945) and Lado (1957) introduced the term into the L2 field of language learning. Those researchers have stood on the notion that learners tended to transfer the characteristics of their first language into $L 2$ which they were learning.

There are two types of transfer which occur in $L 2$ learning, positive and negative transfers (Richards \& Schmidt, 2013 and Saville and Troike, 2006). Positive transfer refers to the SLA process in which the $L 1$ concept is closely aligned with that of $L 2$, so that $L 2$ learners could get benefit from their prior knowledge with regard to their $L 1$, when they are trying to learn L2. On the other hand, a negative transfer occurs when the L1 concept is not well-aligned with the concept of $L 2$, so that the concept of $L 1$, which they already have in their mind, could potentially drive the learner to misunderstands the L2 (Kasper, 1992). Such negative transfer is also called as language interference (Newmark in Krashen, 1981; Ellis, 1985). In the following section we discuss more detailed about the language interference phenomenon.

\subsection{Language Interference; One side of language Transfer}

Language interference refers to the negative influence/transfer of $L 1$ when a learner learns L2. The term of Language interference was first introduced by Weinreich in 1953. One of language learning areas which is mostly interfered to each other is language grammar. In Indonesian context for example, a number of researchers have proved that there is a big chance that Indonesian grammatical aspect could interfere that of English. Students may express "We do our homework with easy" as a translation of "Kami mengerjakan PR itu dengan mudah". This sentence is incorrect. It should be "We do our homework easily". It happens because Indonesian adverb of manner rule is used by the students in constructing the English sentences. In Indonesian, adverbial of manner may be expressed by prepositional phrase 'dengan mudah'. It is lexically transferred into English. Unfortunately, it is wrong. Such adverb of manner in English is expressed by adjective 'easy' plus suffix -ly. The process that is responsible for this is language interference.

Overall, Lane \& Lange (1993) suggested that we can identify three levels of errors in students' writing, in which language interference might occur, namely, in grammar (sentence level) errors, paragraph level errors (problems with coherence within the paragraphs, summary sentences, linking phrases and other devices), and the whole text level errors (introduction, thesis statement, direct linear text, etc). In sentence level, still according to Lane, J. \& Lange, E. (1993:1), we can identify some typical errors such as: 
articles, Verb tense, Subject Verb Agreement, Singular / Plural, Punctuation, Word Class, Vocabulary and Sentence structure. In Indonesian context, Sidupa (2018), provided empirical research on the existence of the interference phenomenon from Indonesian into English at a syntactic level which includes subject-verb agreement.

Regarding subject-verb agreement, in Indonesian, whatever the subject in a sentence, the verb will be the same. In English, there must be an agreement between a verb with the subject. When using a singular subject, for example, we need to use singular verb (See: Sargeant, 2007). Moreover, verb should also agree with its subject in number and person, based on the number, subject can be divided into Singular and Plural. Meanwhile, when the subject of a sentence is in the form of person, there are at least 16 possibilities for the form of the verb (see: Greenbaum and Nelson, 2002; Faidlal, 2007; and Sargeant, 2007).

\subsection{Errors and Mistakes}

Researchers in this filed have identified that errors are caused by learners' inadequate knowledge of the target language while mistakes are slips of the pen or tongue. L 2 learners can self-correct their mistakes but they cannot self- correct the errors they make (see: Manan, Et al 2017; Mourtaga, 2004). Mistakes are not a result of deficiency in competence (Yuksel, 2007), instead they can be considered as lapses which may result from memory failure and physical and mental fatigue. Moreover, Farooq (1998) adds that mistake is also caused by the lack of attention, carelessness and some aspects of performance. Meanwhile, error is systematic (Gass and Selinker, 2008: 102). It is likely to occur repeatedly and is not recognised by the learner as an error (Ellis, 1997).

With respect to language interference, Bates, et.al (1993) in McMartin-Miller (2014) divides errors into three types; (1) global error, which includes incorrect verb tenses, verbs incorrectly formed, incorrect use or formation of modal verbs, incorrect use or formation of conditional sentences, incorrect sentence structure, incorrect word order, incorrect connectors, incorrect use of the passive voice, and unclear messages, (2) local errors, including incorrect subject-verb agreements, incorrect or missing articles, problems with the singular or plural of nouns, wrong word choices, wrong word forms and non-idiomatic or not appropriate collocation expressions, and (3) other errors, including errors of capitalization, coherence, comma splices, dangling modifiers, fragments, lower case use, errors in punctuation, run-on sentences, spelling errors and more collocation errors. Considering a number of limitations which we had in conducting this research, we only focused on local error, especially on subject-verb agreement. In this research, we identify an error through error analysis, which in more specific, we discuss in subsection below.

\subsection{Error Analysis}

Error analysis is the analysis of errors made by the learners while learning ESL (Shahin, 2011 and Erdogan, 2005). This analysis contributes for analysing the corpus language of the performance, discovering the errors and occurs not only because of the interference, but it resembles the developmental errors for the child learning the first language. Brown (2007) claims, these errors are observable, analysable, and can be classified. In this regard, Norrish's (1992) and James (1998) have proposed ways in conducting error analysis which likely has been adopted by most researchers in this filed. Norrish's (1992) proposed a number of steps to take in conducting the error analysis, which includes sample collection 
and errors identification, description, explanation and evaluation. Moreover, James (1998) conducted error analysis by asking participants to write 200 to 300 words narrative essay. He decided what topic to write by the participants. The data was then analysed, and the errors were described and discussed. In this research we developed the steps of conducting error analysis by incorporating the steps proposed by those both researchers. We discuss such strategic steps in more detailed in research methodology section, later on. In the following subsection we present discussion regarding contrastive analysis, which we will adopt in order to follow up data collected from the error analysis.

\subsection{Contrastive Analysis}

Contrastive analysis is a way of comparing languages in order to determine potential errors and to isolate what needs to be learned and what does not need to be learned in a ESL learning (see: Gass and Selinker, 2008) and to develop the linguistic differences between the learners' L1 and L2 (Brogan and Son, 2015). Overall, Ellis (1985) provides two hypotheses of contrastive analysis; strong form and the weak form. The strong version states that it is possible to contrast the system of one language (the grammar, phonology, and lexicon) with a system of a second language in order to predict the difficulties which a speaker of second language will have in learning a first language, and to construct a reading material to help her to learn that language. The weak version is the linguist uses the best linguistic knowledge available to him in order to account for the observed difficulties in second language learning. This approach makes fewer demands of contrastive theory than the strong version. The starting point of this approach is provided by real evidence from such phenomena as false translation, learning difficulties and residual foreign accents.

In summary, contrastive analysis describes the structural differences and similarities of two or more languages. This hypothesis claims that difficulties in language learning derived from the distinction between the new languages with the learners' first language. Interference as the term used to express the error caused by the distinction of learners' first language and foreign language (FL). Interference as the term used to express the error caused by the distinction of the leaner's first language and foreign language can be predicted and remedied by the use of Contrastive Analysis. The contrastive hypothesis needs to be recognized due to their roles in language learning. In this research, contrastive analysis has a central role in identifying the interference of Indonesian into English by comparing the structures of those two languages. In the following section we describe the research methodology designed in order to conduct this research, in which the contrastive analysis was adopted.

\section{Research Methodology}

\subsection{Research Design}

The form of research adopted in this research is a descriptive study, which was selected due to its nature that enable researchers to describe and interpret the situation which exists now. In addition, it is also able to gather information with regard to the status of an indication when the research is being conducted (see: Ary et al., 1982). In this research the descriptive study was adopted in order to meet the purpose of study, which is to describe how subject - verb agreement pattern of Indonesian language interfere with that of English. 


\subsection{Research Population and Sample}

The research we are reporting in this article was conducted in IKIP PGRI Pontianak, especially in English education study program. The participants of this research were around one hundred preservice English teachers who were registered in the sixth semester of the English education study program. However, in order to make the data collection more effective and efficient in terms of time and financial (see: Banister, 2009; and Dawson, 2002), we only involve 25 of them as the sample of this research. The sample was selected using random sampling technique (see: Wolf, 2005).

\subsection{Data Collection Technique and Instrument}

To collect the data, we adopted the texts and documents study technique (See: Silverman, 2000). In this regard, to collect the data needed in this research, we analysed research outlines written by 25 preservice teachers, who were involved as the sample of this research. The research outlines were a 5 to 7 pages research plan written by preservice teacher, as a compulsory requirement in proposing the research subject for their thesis. Nonetheless, with limitation we had in conducting this research, we only analysed the background section of the research outlines, which consist of two to three $\mathrm{A}_{4}$ pages.

\subsection{Data Analysis Procedures}

To analyse the data collected in this research, we went to two main distinct steps extracted from those suggested by Norrish's (1992) and James (1998), namely identification and clarification processes. Identification process was designed to identify every incorrect sentence, in terms of its subject-verb agreement, which were caused by learners' error. To do so, we adopted error analysis (see: Brogan and Son 2015; Erdogan, 2005; and Shahin, 2011). Meanwhile, clarification process was conducted to clarify whether or not each error sentence identified in identification process was caused by the interference of Indonesian grammatical aspects into English. In doing so, we applied contrastive analysis technique (See: Gass and Selinker, 2008; Brogan and Son 2015; James, 1998 and Ellis, 1985).

In identification process, in order to ease the recapitulation process, we underlined each sentence which were incorrect in terms of its subject-verb agreement. Then, each incorrect sentence was classified into mistake and errors, based on the criteria proposed by Manan Et al. (2017); Yuksel (2007); Mourtaga (2004);

Farooq (1998); Gass and Selinker (2008); Ellis (1997); and Bates, et.al (1993) in McMartinMiller (2014). Then through clarification process, the grammatically incorrect sentences were then classified further into the one(s) which was caused by the interference of first language and the one(s) which was caused by other factors. Eventually, we calculated the number of grammatically incorrect sentences which were caused by the interference of Indonesian on each sample and on the whole sample. Overall, the strategic steps we developed in order to collect and analyse the data, as we discuss above, have been able to provide adequate data in order to answer the research question which shaped the research we are now reporting. In the following section, we discuss the finding of this research.

\section{Findings}

The analysis of data collected in this research through both identification and clarification processes show that a number of ungrammatical sentences which were classified as error 
have been found. Some of the error sentences were identified as caused by the interference of Indonesian subject-verb agreement pattern into that of English. In this section we present in more detailed regarding such findings.

The identification process revealed a number of grammatically incorrect sentences in terms of subject-verb agreement. Such sentences could be classified into six out of 15 types of subject-verb agreement, as discussed in subsection 2.3. we present such identified sentences in Table 1 below.

Table 1. Six type of subject-verb agreements which are written incorrectly

\begin{tabular}{|c|c|c|c|c|}
\hline No & $\begin{array}{l}\text { Types of } \\
\text { Agreement }\end{array}$ & $\begin{array}{l}\text { Types } \\
\text { code }\end{array}$ & Sample of Error Sentences & $\begin{array}{l}\text { Students' } \\
\text { code }\end{array}$ \\
\hline 1 & $\begin{array}{l}\text { Singular } \\
\text { Subject }+ \\
\text { Singular } \\
\text { Verb }\end{array}$ & T01 & $\begin{array}{l}\text { EFL learner in general are relatively poor at } \\
\text { spoken English... } \\
\frac{\text { Correct Sentence: EFL learner in general is }}{\text { relatively poor at spoken English... }}\end{array}$ & So1 \\
\hline 2 & $\begin{array}{l}\text { The use of } \\
\text { to be. }\end{array}$ & To2 & $\begin{array}{l}\text { But if someone poor in listening he/she cannot } \\
\text { communicate... } \\
\text { Correct Sentence: But if someone is poor in } \\
\text { listening, he/she cannot communicate... }\end{array}$ & So2 \\
\hline 3 & $\begin{array}{l}\text { Plural } \\
\text { subject }+ \\
\text { Plural verb }\end{array}$ & To3 & $\begin{array}{l}\text {...the students in this club needs certain } \\
\text { attention... } \\
\text { Correct Sentence: ....the students in this club } \\
\text { need certain attention... }\end{array}$ & So6 \\
\hline 4 & $\begin{array}{l}\text { Modal } \\
\text { auxiliary + } \\
\text { V1 bare } \\
\text { infinitive }\end{array}$ & To4 & $\begin{array}{l}\text { A discussion may gives a big ... } \\
\text { A discussion may give a big ... }\end{array}$ & So6 \\
\hline 5 & $\begin{array}{l}\text { Two } \\
\text { subjects } \\
\text { combined } \\
\text { by "and" + } \\
\text { plural verb }\end{array}$ & T05 & $\begin{array}{l}\ldots \text { arising and developing the students'interest is } \\
\text { not an easy effort. } \\
\ldots \text { arising and developing the students' interest } \\
\text { are not an easy effort. }\end{array}$ & $\mathrm{S}_{12}$ \\
\hline 6 & $\begin{array}{l}\text { Two } \\
\text { subjects } \\
\text { separated } \\
\text { by "or" }\end{array}$ & To6 & $\begin{array}{l}\text { Implicit messages or trusteeship appear in source } \\
\text { language and retell in the target language. } \\
\text { Implicit messages or trusteeship appears in } \\
\text { source language and retells in the target } \\
\text { language }\end{array}$ & $\mathrm{S}_{16}$ \\
\hline
\end{tabular}

As can be observed in table 1 above, there are six types of English subject-verb agreement pattern which were written incorrectly by the preservice teachers. Upon those incorrect sentences, we conducted further identification in order to find out whether the sentences were caused by error or mistakes. The analysis conducted in this process identified a number of grammatically incorrect sentences which were caused by preservice teachers' errors, as presented in Table 2 below. 
Table 2. Error analysis on the students' ungrammatical sentences

\begin{tabular}{|c|c|c|c|}
\hline $\begin{array}{l}\text { Code of } \\
\text { agreement } \\
\text { types }\end{array}$ & Sentences & Error Analysis & Classification \\
\hline \multirow[t]{2}{*}{ T01 } & $\begin{array}{l}\text { 1.EFL learner in general are } \\
\text { relatively poor in at spoken } \\
\text { English... }\end{array}$ & $\begin{array}{l}\text { There were } 8 \text { sentences in this } \\
\text { form, only } 3 \text { which were } \\
\text { incorrect. }\end{array}$ & MTS \\
\hline & $\begin{array}{l}\text { 2.The listener get left } \\
\text { behind.... }\end{array}$ & $\begin{array}{l}\text { There were } 3 \text { sentences in this } \\
\text { form, all of them are incorrect. }\end{array}$ & ERS \\
\hline \multirow[t]{2}{*}{ T02 } & $\begin{array}{l}\text { 3. But if someone poor in } \\
\text { listening he/she cannot } \\
\text { communicate ... }\end{array}$ & $\begin{array}{l}\text { There were } 9 \text { sentences in this } \\
\text { form, only } 1 \text { which were } \\
\text { incorrect. }\end{array}$ & MTS \\
\hline & $\begin{array}{l}\text { 4.... English } \underline{\text { be taught since }} \\
\text { they are as young learner... }\end{array}$ & $\begin{array}{l}\text { There were } 3 \text { sentences in this } \\
\text { form, all of them were } \\
\text { incorrect. }\end{array}$ & ERS \\
\hline \multirow[t]{2}{*}{ T03 } & $\begin{array}{c}5 . . . \text { the students in this club } \\
\text { needs certain attention ... }\end{array}$ & $\begin{array}{l}\text { There were } 3 \text { sentences in this } \\
\text { form, all of them were } \\
\text { incorrect. }\end{array}$ & ERS \\
\hline & $\begin{array}{l}\text { 6. Vocabularies is given by the } \\
\text { teacher }\end{array}$ & $\begin{array}{l}\text { incorrect. } \\
\text { There were } 10 \text { sentences in this } \\
\text { form, only one which were } \\
\text { incorrect. }\end{array}$ & MTS \\
\hline \multirow[t]{2}{*}{ T04 } & $\begin{array}{l}\text { 7.a discussion that may gives } \\
\text { a big ... }\end{array}$ & $\begin{array}{l}\text { This sentence was the only one } \\
\text { mistake which happened. }\end{array}$ & MTS \\
\hline & 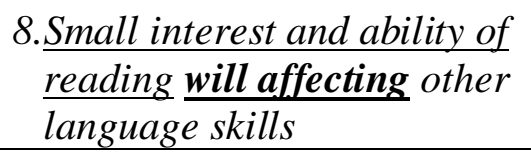 & $\begin{array}{l}\text { This sentence was the only one } \\
\text { mistake which happened. }\end{array}$ & MTS \\
\hline \multirow[t]{2}{*}{ T05 } & $\begin{array}{l}\text { 9.... arising and developing } \\
\text { the students' interest } \underline{\text { is }} \text { not } \\
\text { an easy effort. }\end{array}$ & $\begin{array}{l}\text { There were } 2 \text { sentences in this } \\
\text { form, all of them were } \\
\text { incorrect. }\end{array}$ & ERS \\
\hline & $\begin{array}{l}\text { 10. Dechant and Smith (1977, } \\
\text { p. 109) remarks that.... }\end{array}$ & $\begin{array}{l}\text { This sentence was the only one } \\
\text { mistake which happened }\end{array}$ & MTS \\
\hline To6 & $\begin{array}{l}\text { 11. Implicit messages or } \\
\text { trusteeship appear in source } \\
\text { language and retell in the } \\
\text { target language. }\end{array}$ & $\begin{array}{l}\text { There were } 2 \text { sentences in this } \\
\text { form, all of them were } \\
\text { incorrect. }\end{array}$ & ERS \\
\hline
\end{tabular}

Note: $\quad$ MTS $=$ Mistake sentence

ERS $=$ Error sentence

As can be noted from table 2 above, a number of grammatically incorrect sentences, which were caused by students' errors have been identified. To find out whether or not such errors were caused by the interference of Indonesian into English, we conducted clarification process, using contrastive analysis. In section below, we present the finding of such process. Findings from Classification process 
In clarification process, we compared Indonesian subject-verb agreement concept into English. such processes revealed that there were four types of English subject-verb agreement pattern which were interfered by that of Indonesian. As presented in Table 3 below.

Table 2. Error analysis on the students' ungrammatical sentences

\begin{tabular}{|c|c|c|c|}
\hline No. & $\begin{array}{l}\text { Types of S-V } \\
\text { agreement in } \\
\text { English }\end{array}$ & $\begin{array}{l}\text { S-V agreement pattern in } \\
\text { Indonesian }\end{array}$ & $\begin{array}{l}\text { Example of error written by } \\
\text { participants }\end{array}$ \\
\hline 1 & $\begin{array}{l}\text { Singular } \\
\text { Subject }+ \\
\text { singular verb }\end{array}$ & $\begin{array}{l}\text { In Indonesian's, whatever the } \\
\text { subject, the verb would be } \\
\text { similar }\end{array}$ & $\begin{array}{l}\text { - The listener get left behind.... } \\
\text { - ... teacher read it loudly or ask } \\
\text { the students to repeat it }\end{array}$ \\
\hline 2 & $\begin{array}{l}\text { Plural subject + } \\
\text { plural verb }\end{array}$ & $\begin{array}{l}\text { In Indonesian's, whatever the } \\
\text { subject, the verb would be } \\
\text { similar }\end{array}$ & $\begin{array}{l}\text {... all of the items oblige } \\
\text { students... }\end{array}$ \\
\hline 3 & $\begin{array}{l}\text { The use of to } \\
\text { be }\end{array}$ & $\begin{array}{l}\text { the nominal sentence in } \\
\text { Indonesian does not need a to be }\end{array}$ & $\begin{array}{l}\text { A good translator not only able to } \\
\text { solve... }\end{array}$ \\
\hline 4 & $\begin{array}{l}\text { Two subjects } \\
\text { separated by } \\
\text { "or" }\end{array}$ & $\begin{array}{l}\text { In Indonesian the subject which } \\
\text { are separated by or and any } \\
\text { kinds of subject would affect } \\
\text { nothing toward the verb }\end{array}$ & $\begin{array}{l}\text { Implicit messages or trusteeship } \\
\text { appear in source language and } \\
\text { retell in the target language }\end{array}$ \\
\hline
\end{tabular}

\section{Discussion}

The analysis of data collected in this research confirmed the interference of Indonesian subject - verb agreement pattern into English by preservice teachers. It is in line with the empirical evidences reported by previous researchers in this field. Ellis (1994), for example, described that two languages having distinct linguistic structures may result in a high frequency of errors in the target language which in turn indicates an interference of $L 1$ on L2. Furthermore, Gao (2013) reported that the learner who comes in contact with a foreign language may resort to his/her native language features to replace those difficulties in the target language. Each of the researchers has provided evidence in relation to language contact in different context and methodology. The finding we are now reporting provide empirical evidences to support researchers who investigated the interference to English, from German and Italian (Forsyth, 2014), Chinese (Guo, Liu, \& Chen, 2014; and Wang, 2015), Russian (Galkina and Radyuk, 2019), Arabic (Thyab, 2016 and Sabbah, 2015), and Turkish (Erarslan and $\mathrm{Hol}, 2014$ ).

In Indonesian context, the finding of this research also strengthen the findings reported by a number of researches, such as Azis, Daud \& Yunidar (2019); Sidupa (2018); Irmalia (2016); Ghufron (2015); Pudiyono (2012); and Alwasilah (1985), which reported the interference of Indonesian grammatical aspects into English. Such decades-long researches have proved that ESL learning was interfered by Indonesian language. The interference occurred in four types of English subject - verb agreement patterns. Such finding supported those reported by McMartin-Miller (2014), Amin (2017) and Gass and Selinker (2001). In Indonesian context, the finding which we are now reporting support those reported by Sidupa (2018) and Alwasilah (1985), which provided empirical evidence on the existence of the interference 
phenomenon from Indonesian into English at a syntactic level which includes subject-verb agreement.

Moreover, based on our reviews toward a number of previous research reports, we assumed that there were two potential factors which might have caused the interference to occur. Firstly, the natures of Indonesian subject-verb agreement pattern which tend to be flexible, that make Indonesian grammatical rules do not require special agreement between subject and verb, might make the interference be more possible to occur. The long distance between the concept of English subject-verb agreements with that of Indonesians make the errors have bigger chance to occur (see: Irmalia, 2016; Guo, liu \& Chen 2014; Ghufron, 2015; Kotz, 2009; and Zawiszewski et al. 2011). Secondly, the lack of knowledge of the preservice teachers regarding the pattern of subject-verb agreement in English made the chance for such interreference to occur even bigger. Such preservice teachers used their prior knowledge regarding Indonesian concept of subject-verb agreement when they write their research outline, in English (see: McMartin-Miller, 2014; Micheal and Bernard, 2001; Ellis, 1994; Amin, 2017; and Gass and Selinker, 2001). However, further follow up researches are still needed in order to provide empirical evidences in supporting the assumptions above.

Furthermore, as illustrated in Table 1 , the errors and mistakes were differed from one respondent to others. A sentence was a mistake for a student and become an error for others. It showed the variants of linguistic understanding of each of the respondents. The difference of level and area of their understanding regarding subject-verb agreement patterns in English make them have various areas of errors and mistakes.

The finding of this research provided further empirical basis for policy makers in improving their policies and practices in terms of supporting preservice teachers in learning ESL (see: Brogan and Son 2015; Shahin, 2011; Erdogan, 2005; Yusuf, 1994; and Norrish, 1983). For lecturers, the finding of this research revealed the nature of language learning processes, especially with regard to the way and the progress of ESL learners' learning (see: Shahin, 2011and Erdogan, 2005). The errors identified through this research could be beneficial information in order to improve understanding regarding the second language-learning process and to help the stakeholders implementing effective changes in classrooms level (see: Brogan and Son, 2015).

In addition, the data regarding preservice teachers' errors could indicate the information regarding the source of the errors, which could be used to inventory and map the errors made by preservice teachers. Such information can be used by policy makers to develop its policies and practices regarding developing the efforts of anticipating the occurrences of interferences in ESL leaning to occur (see: Erdogan, 2005; and Norrish, 1983). Furthermore, the finding regarding the four types of English subject-verb agreement pattern, which were interfered by that of Indonesian, could be beneficial for teachers to indicate the actual acquisition process in preservice teachers ( see: Yule, 1996; and James, 1998) and to identify the most difficult part of English subject-verb agreement patterns and error types which most detract from preservice teachers' ability to write in English effectively (see: Erdogan, 2005).

For preservice English teachers, the data regarding the errors and mistakes they made, as reported in this research, could be beneficial consideration in improving their own learning (see: Erdogan, 2005 and Griffiths, 2008). The data regarding the mistakes and errors could 
be an empirical data for the preservice teachers and policy makers in developing strategic plans to addressing each of their error. Doing so is important, as Griffiths (2008) and Harmer (2003) believe that some mistakes need to be addressed sooner and continuously, unless they will be fossilised.

\section{Conclusion}

The analysis on data collected in this research proved that the preservice English teachers, who were involved in this research, transfer Indonesian subject-verb agreement concept into some types of that of English. Such data provide empirical evidence in supporting the assumption which had previously been developed as the standing point of this research, which assumed that the learning constraints faced by preservice English teachers in constructing correct English sentences, especially in subject-verb agreement concepts, were caused by the negative transfer of Indonesian into English. The interference occurred due to the lack of knowledge of the preservice teachers regarding the pattern of subject verb agreement in English. Errors and mistakes happened very individually, that the errors and mistakes made by each of the preservice teachers were also different. It means that the mistake or errors of every participant was different from each other. An ungrammatical sentence was mistake in a student but was error in the other ones

\section{References}

Amin, A.K. (2017). Linguistic Analysis of the Phenomenon of Language Transfer. IOSR Journal of Humanities and Social Science (IOSR-JHSS), 22 (4).

Azis, Z.A., Daud, B., \& Yunidar, S. (2019). Second Language Interference towards First Langauge Use of Japanese Learners. Indonesian Journal of English Language Teaching and Applied Linguistics, 4(1).

Dweik, B.S. \& Othman, Z.A. (2017). Lexical and Grammatical Interference in the Translation of Written Texts from Arabic into English. Academic Research International, 8 (3).

Brogan, F.D., Son, J. (2015). Native Language Transfer in Target Language Usage: An Exploratory Case Study. Permalink. Voices, 3(1).

Brown, H. (2007). Principles of language learning and teaching. ( $5^{\text {th }} \mathrm{Ed}$.). New Jersey: Pearson Educated Limited.

Dawson, C. (2002). Practical Research Methods. Oxford: How to Book Itd.

Ellis, R. 1985. Understanding foreign language Acquisition. New York: Oxford University Press.

Dulay, H., Burt, M. and Krashen, S. (1982). Language Two. New York: Oxford University Press.

Ellis, R. (1997). Second Language Acquisition. Oxford: Oxford University Press.

Ellis, R. (1994). The study of Second Language Acquisition. New York: Oxford University Press.

Erarslan, A \& Hol, D. (2014). Language Interference on English: Transfer on the Vocabulary, Tense and Preposition Use of Freshmen Turkish EFL Learners. ELTA Journal, 2 (2), 422.

Erdocia, K. and Laka, I. (2018). Negative Transfer Effects on L2 Word Order Processing. Front. Psychol, 9 (337). doi: 10.3389/fpsyg.2018.00337 
Erdogan. (2005). Contribution of Error Analysis to Foreign Language Teaching. Mersin University Journal of the Faculty of Education, 1 (2).

Farooq, M. U. (1998). Contrastive and Errors Analysis based Teaching Strategies. Aichi Women's Junior College press

Forsyth, H. (2014). The Influence of L2 Transfer on L3 English Written Production in a Bilingual German/Italian Population: A Study of Syntactic Errors. Open Journal of Modern Linguistics, 4, 429-456. http://dx.doi.org/10.4236/ojml.2014.43036

Galkina, A. and Radyuk, A.V. (2019). Grammatical interference in written papers translated by Russian and American students. Training, Language and Culture, 3 (3), 89-102, doi: 10.29366/2019tlc.3.3.6

Gao, H. (2013). On Source Language Interference in Interpretation. Theory and Practice in Language Studies, 3(7), 1194-1199. doi:10.4304/tpls.3.7.1194-1199

Gass and Selinker. (2008). Second Language Acquisition. An introductory course. Third edition. New York: Routledge

Ghufron, M.A. (2015). Interference in Learning English: Grammatical Errors in English Essay Writing Among Seventh Graders Of Mts Darul Ulum, Sukosewu, Bojonegoro, East Java English Teaching Journal, 3 (2).

Greenbaum, S \& Nelson, G. (2002). An Introduction to English Grammar. Second Edition. London: Pearson Education

Griffiths, C. (2008). Strategies and good language learners. In C. Griffiths (Ed.), Lessons from good language learners. Cambridge: Cambridge University Press

Guo, M., Liu, J., Chen, P. (2014). A Case Study on the Effect of Chinese Negative Transfer on English Writing. Theory and Practice in Language Studies, 4 (9), 1941-1947. doi: 10.4304/tpls.4.9.1941-1947

Harmer, J. (2003). The Practice of English Language Teaching. Harlow: Pearson Education

Irmalia, M. (2016). Indonesian Interference in Students' Writing. English Education Journal (EEJ). 7(4), 496-508.

James, C. (1998). Errors in Language Learning and Use. Exploring Error Analysis. London \& New York: Longman.

Kotz, S. A. (2009). A critical review of ERP and fMRI evidence on L2 syntactic processing. Brain Lang. 109, 68-74. doi: 10.1016/j.bandl.2008.06.002

Lane, J. \& Lange, E. (1993). Error Analysis Handout for Students. La Trobe University Journal.

Krashen, S. (2002). Second Language Acquisition and Second Language Learning, Internet Edition. California: Pergamon Press Inc.

Manan, N.A., et al. (2017). Mother Tongue Interference in the Writing of English as a Second Language (ESL) Malay Learners. International Journal of Academic Research in Business and Social Sciences. 7 (11) ISSN: 2222-6990.

McMartin-Miller, C. (2014). How much feedback is enough?: Instructor practices and student attitudes toward error treatment in second language writing. Assessing Writing, 19, 24-35.

Mourtaga, K. R. (2004). Investigating Writing Problems among Palestinian Students: Studying English as a Foreign Language. Bloomington, Indiana: Author House.

Norrish, J. (1992). Language learners and their errors. London: Macmillan Publishers

Odlin, T. (1989). Language Transfer: Cross-Linguistic Influence in Language Learning. Cambridge: Cambridge University Press. http://dx.doi.org/10.1017/CBO9781139524537 
Poplack, S. (1983). Bilingual Competence: Linguistic Interference or Grammatical Integrity? New York: University of New York.

Pudiyono. (2012). Educational Research: Grammatical Interference towards the Students' Spoken and Written English. International Journal for Educational Studies, 4 (2), 29224.

Sabbah, S.A. (2015). Negative Transfer: Arabic Language Interference to Learning English. Arab World English Journal (AWEJ). (4), 269-288.

Sajavaara, K. (1986). Transfer and second language speech processing. Avon: Multilingual Matters.

SattiHamad, M., \& Yassin, A. (2015). Investigating lexical errors and their effect on university students' written performance in Sudan. SUST Journal of Humanities, 16, (1), 1-18.

Saville and Troike. (2006). Introducing Second Language Acquisition. New York: Cambridge University Press.

Shahin, N. (2011). Error treatment in TESOL classroom. Jordan Journal of Applied Science: Humanities Series, 13(1), 207-226. Retrieved from http://www.asu.edu.jo/asu/userfiles/file/HumanitiesSeries-pdf

Sidupa, C. (2018). Indonesian Language Transfer of Students of English as a Second Language (ESL). The 1st International Seminar on Language, Literature and Education.

Silverman, D. (2000). Doing Qualitative Research. A Practical Hand Book. London: SAGE Publication.

Thyab, R.A. (2016) Mother-Tongue Interference in the Acquisition of English Articles by L1 Arabic Students. Journal of Education and Practice, 7(3).

Warsono. (2016). Language Transfer in Learner Language. Journal of English Education, Literature, and Culture, 1.

Wang, Y. (2015). Negative transfer of mother language in English compositions by Jiujiang university students. In SHS Web of Conferences (Vol. 14, p. 01008). EDP Sciences.

Weinreich, U. (1953). Languages in Contact. The Hague: Mouton.

Wolf, R. M. (2005). Judging educational research based on experiments and surveys: International Institute for Educational Planning/UNESCO.

Yuksel, G. (2007). Grammatical Errors in the Compositions Written by Turkish Learners of English. Published Master Thesis. Erzrum: Ataturk University.

Yule, G. (1996). The Study of Language. Cambridge: Cambridge University Press

Zawiszewski, A., Gutiérrez, E., Fernández, B., \& Laka, I. (2011). Language distance and nonnative syntactic processing: Evidence from event-related potentials. Bilingualism: Language and Cognition, 14(3), 400-411. 